\title{
Policy Diffusion and Innovation: Media and Experts in Colorado Recreational Water Rights
}

\author{
DESERAI A. CROW* \\ *Journalism and Mass Communication and Environmental Studies Program, University of Colorado Boulder, \\ Boulder, CO, USA
}

\begin{abstract}
Beginning in 1998, an innovation in water rights policy took place in Colorado. This paper analyses the diffusion of the recreational in-channel water right policy innovation among Colorado communities. This research involved in-depth case studies in 12 Colorado communities. Data include interviews, legal and legislative documents, and mass media coverage. These new water rights spread among Colorado communities through two processes. First, experts acted as information entrepreneurs providing both technical and policy information to other communities. Through repetitive journalistic sourcing, media coverage spread the influence and reputation of certain experts who then influenced internal policy decisions in subsequent communities.
\end{abstract}

How and why policies spread between communities are the questions that drive scholarship on policy diffusion. Through forces of economic competition (Boehmke \& Witmer, 2004), social learning (Glick \& Hays, 1991), or like a contagion (Boushey, 2010), scholars posit that certain conditions make policy diffusion more likely. This study seeks to apply these lessons that are derived primarily from state-level research to local environmental policymaking in order to accomplish two goals: to understand similarities and differences between these two levels of policymaking, and to analyse policy diffusion concepts in the context of a particularly technical area of environmental policymaking in order to further refine our understanding of the likelihood of technical policy change.

This study analyses the diffusion of policies within one case study in Colorado that spans 12 communities. By analysing the process by which a new policy spreads through these communities and the influences over the processes of diffusion, this paper contributes to the expanding literature that seeks to explain how and why environmental policies evolve, change, and influence others within the local government context. Environmental policy scholarship has historically acknowledged the importance of analysing local policy processes due to the significant role that these policies play in environmental outcomes (Busenberg, 2008; Layzer, 2002; Nicodemus, 2004). The local government context is

Correspondence Address: Deserai A. Crow, Journalism and Mass Communications and Environmental Studies Program, University of Colorado Boulder, Armory Building, 1511 University Avenue, 478 UCB, Boulder, CO 80309, USA. Email: deserai.crow@ colorado.edu

ISSN 1939-0459 Print/1939-0467 Online (C) 2012 Taylor \& Francis http://dx.doi.org/10.1080/19390459.2012.642635 
appropriate for this study because it provides a discrete set of cases in a single policy domain, under a single state system, from which findings and conclusions can be drawn. The findings presented here, however, have implications beyond local government and beyond the state of Colorado. This study seeks answers to the following research questions: How do local governments learn about new policy options? And, how do technical policy options diffuse through a network of communities?

\section{The Diffusion of Policies and the Role of Information Therein}

How and through what mechanisms policies spread from state to state, or locality to locality, are the questions that drive the many studies of policy innovation and diffusion (Dolowitz \& Marsh, 2000). In the theory of policy diffusion, governments learn from the experiences of other governments (Michaels et al., 2006). In local policy decisions, information and policy are connected in this cycle of policy change. Learning from others can happen simply by observing the behaviour of other actors in a policy process, and can lead to a convergence of behaviour around particular options or alternatives (Bikhchandi et al., 1998). This diffusion, then, can also lead to opportunities for further innovation around the diffused policies, or a process of reinvention (Glick \& Hays, 1991; Hays, 1996).

Within states, policy innovation happens based upon two forces (Boehmke \& Witmer, 2004). First, the process of social learning takes place, wherein officials draw upon the experiences of other governments when deciding to pursue a new policy. Presence of neighbouring states with a specific policy in effect increases the likelihood of further diffusion of that policy (Berry \& Berry, 1990). Through "satisficing" (Simon, 1976), officials systematically search for and consider policy alternatives that have previously been used by neighbours and governments with similar needs until one that best satisfies the needs of the local policy situation is found. Second, economic competition can drive other entities to adopt policies due to potential increases or decreases in revenue and competition for jobs, taxes, and other economic benefits (Berry \& Berry, 1990). The majority of the research on policy diffusion and the role of policy knowledge focuses on state-level actors. Increasingly, scholars are working to understand these processes in the context of local government decisions as well (Bingham, 1978; Godwin \& Schroedel, 2000; Hoyman \& Weinberg, 2006). Innovation in local governments may have as much to do with organizational size and resource availability as any other factor, according to some scholars (Bingham, 1978).

The social learning that takes place and influences policy adoption is a complex process, but like many cognitive processes is based upon cues or heuristics (Grossback et al., 2004) that help to reduce the uncertainty of policy adoption and decisions. Based upon this logic of bounded learning, Meseguer (2006) finds that countries are highly influenced by neighbouring countries' successful policy experiences. This supports previous findings on American state policy diffusion (Berry \& Berry, 1990). The political and social linkages between policy actors and states serve as cues and therefore increase the likelihood of policy diffusion or transfer (Tews et al., 2003). Based on the assertions presented above, we would expect policy communities that are geographically or socially linked in some manner to experience higher levels of policy transfer. We should also see that later cases of policy transfer might involve an economic competition component as a reason for policy diffusion.

Boushey (2010) builds on the many previous studies of policy diffusion to create a theoretical model that accounts both for the slow process of policy diffusion that is most often 
exhibited in American states as well as periods of rapid policy diffusion. His model borrows from epidemiology and posits that policy diffusion can be modelled similar to the spread of a disease. As such, it is important to understand the characteristics of 1) the policy (disease), 2) the state actor (host), and 3) the vector (transmission mechanisms). Policies that are characterized by high saliency and low transaction costs will diffuse faster, while technocratic policies will diffuse slower. With regard to state actors, professional legislatures will be more prone to promote technocratic change, while citizen legislatures will be more likely to lag and follow the experiences of others. Finally, interest groups will be integral in promoting diffusion across jurisdictions. Some also argue for greater consideration of the role of policy entrepreneurs in the diffusion of policy innovations (Mintrom, 1997).

Because the spread of information related to new policies is an important component of policy diffusion, it is necessary to consider the role of information in policymaking. The uptake of knowledge from experts by policymakers is considered an important element of the process of policy change, especially in environmental policymaking where technical decisions are commonplace (Michaels et al., 2006). Policy information is widely produced, but its usefulness to decision makers is questionable. Some scholars (see Webber, 1991 for example) argue that despite the prevalence of policy information and analysis, decision makers do not seem to use these information sources in their decisions to improve decisionmaking. Studies indicate that rarely is this information or analysis used in forming policy decisions and rarely is it used in an attempt to improve policymaking, despite the desire for such outcomes on the part of policy scientists (Miller, 1989). "Policy elites at the centre of the state are relying too much on. . . deductive reasoning, policy templates, and onedimensional epistemologies" (Bell, 2004).

In the field of environmental policy, scientific or technical information is often incorporated into policy discussions and decisions. This is encouraging for those who advocate a more thorough examination of policy decisions based on knowledge and science (Haas, 2004). A prevalence of policy information related to alternatives, appropriate scientific understanding of natural resources, and methods for environmental policymaking is evident in US environmental policy. This information, however, can be used "by a host of self-interested actors, not an eagerly awaited source of consensus" (Healy \& Ascher, 1995, p. 17). Science can at times be used as a form of technical jargon designed to limit access to policy discussions on the part of citizens (Schneider \& Ingram, 1997). Access to this policy knowledge and technical information can alter the power structure of organizations and political processes. The scholarship related to the role of knowledge and information in policymaking primarily focuses on formal policy analyses and technocratic information. Beyond these types of information, less formal information linkages may exist to help spread policies among networks of communities. Indeed, the role of "local knowledge" and less formal types of information in local policy decisions has gained support as being important to the policy decision process (Fischer, 2005). It is important to consider a wider variety of information and types of knowledge than only technical policy information when assessing how information spreads, through what means, and with what effects.

Based on the literature outlined above, we expect that policies will diffuse more readily among neighbouring governments, professional organizations, and where policies are less technical. We also expect that interest groups or other actors may play important roles in promoting diffusion of new policies. Finally, in an analysis of policy diffusion, it will be important to understand the process through which policy information spreads 
to subsequent governments and the actors involved in this information dissemination and uptake.

\section{Research Methods: Comparative Case Study Analysis}

This research was conducted using Colorado communities that sought recreational water rights for kayaking and white-water rafting, which significantly altered the policy landscape with regard to water rights in Colorado. This comparative case study involved in-depth analysis of the policy process in the 12 communities that chose to pursue this new type of water right in Colorado. The case of recreational water rights is described below, followed by the data collection and analysis procedures.

\subsection{The Case: Recreational Water Rights in Colorado}

In all American states a system of granting use rights to water resources has been established. In the western United States, where water resources are variable and less plentiful (Worster, 1985), these systems are controlled primarily under the system of prior appropriation (Getches, 1997). Under prior appropriation, holders of junior water rights, as determined by the date of appropriation of the resource, are not allowed to take any of their water until the senior water rights holders on the river have fully satisfied their rights.

All water rights holders must put their water to a beneficial use, as designated by a Colorado water court. Colorado's prior appropriation system first only allowed for irrigation water rights (Hobbs, 1997) but over time has evolved to include many other uses of water including domestic, industrial, mining, snowmaking for ski resorts, environmental protection, and other uses (Colorado Foundation for Water Education, 2004). This evolution of uses has most recently included the development of in-channel recreational use of water for maintaining river flows for kayaking and white-water boating. This new water right - the recreational in-channel diversion (RICD) - is the focus of the case study presented here.

In 1998 Golden, Colorado, applied for the first in-channel recreation water right in water court. ${ }^{1}$ As recreation and tourism have become more important economic drivers in Colorado and in many communities, local governments sought policy solutions that would help to establish or protect their recreational resources, such as white-water boating. Golden was followed by Vail, Breckenridge, and nine other communities between 1998 and 2006. Due to intense political opposition to these water rights, the state legislature debated legislation on three separate occasions to codify and restrict the water right, passing two pieces of legislation and defeating a third (Senate Bills 216 [2001]; 62 [2005]; 37 [2006]). The first of these, Senate Bill 216, codified the water right under state law by defining this use of water as a beneficial use, but also limited RICDs to the "minimum amount [of water] necessary for a reasonable recreational experience," language that proved highly contentious. Under state statute only subdivisions of state government (municipalities, counties, water districts, etc.) can own a RICD water right. Later legislation in Senate Bill 37 restricted the timing of the water right to recreation season (1 April until Labor Day), defined recreation in this context as non-motorized boating, and required the construction of engineered white-water park structures to qualify for the RICD water right.

The Colorado Supreme Court heard cases involving four of these communities before the water rights were granted. The first set of cases included Golden, Vail, and Breckenridge. 
These communities' cases were heard before the Colorado Supreme Court before legislation was enacted to codify the RICD, so they fought for the recognition that these water rights were actually a beneficial use of water. These communities presented economic impact studies to show that white-water boating brought significant revenue to the local community and argued that these water rights were therefore beneficial under traditional metrics related to economic value of water use.

Over a decade, this issue rose in importance throughout communities in Colorado. Similar policy debates were held in local communities regarding whether or not to pursue a water right and build the required boating course structures to qualify for such a water right. The policy process within local communities, and among the communities, is the focus of this research. RICD water rights were a politically controversial issue, but in local communities they were also an expensive undertaking (see Table 4 below for a detailed breakdown by community). Communities spent hundreds of thousands of dollars in legal fees associated with the water right (mean cost $=\$ 276714$ ) and building the boating course structures (mean cost $=\$ 378200$ ). Considering that many of these communities have small tax bases (mean population $=21385$ ), this is a significant investment. This calls into question the proposed role that resources and organizational size have in local policy diffusion (Bingham, 1978), and makes this an appropriate case for analysis of local environmental policy decisions and policy diffusion. Table 1 provides a timeline and breakdown of the size of each recreational water right for the communities included in this study.

\subsection{Data Collection and Analysis}

This research was conducted using a comparative case study research design to analyse communities that applied for recreational water rights. Because this study attempts to understand what Yin (2003) describes as complex social phenomena, case study method is the most appropriate and allows understanding of the complete process of policy change

Table 1. Volumetric Increases in RICD Applications over Time

\begin{tabular}{lcc}
\hline Community Name & Cubic Feet Per Second Flow Rate & Year of Application \\
\hline Golden & 1000 & 1998 \\
Vail & 400 & 2000 \\
Breckenridge & 500 & 2000 \\
SB-216 (Passed) & & 2001 \\
Longmont & 350 & 2001 \\
Pueblo & 400 & 2001 \\
Gunnison & 1200 & 2002 \\
Steamboat Springs & 1400 & 2003 \\
Silverthorne & 600 & 2004 \\
Chaffee County & 1800 & 2004 \\
SB-62 (Failed) & & 2005 \\
Avon & 1400 & 2005 \\
Durango & 1400 & 2006 \\
Carbondale & 1600 & 2006 \\
SB-37 (Passed) & & 2006 \\
\hline
\end{tabular}

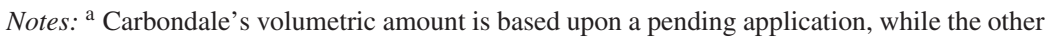
measurements are based upon decreed water rights 
within a community. The 12 Colorado communities that applied for a recreational water right were included in this study.

Three data sources were used within each case study community in order to develop a comprehensive database of the legal and legislative information necessary to analyse the diffusion of RICD policy among Colorado communities. Interviews were conducted with 75 local policy participants and state-wide water experts in Colorado. Local policy participants were identified using two methods: 1) individuals and groups named in media articles and legal or legislative documentation were contacted and interviewed, and 2) those participants were asked for the names of others with whom they interacted during the policy debates, focusing on adequate representation from multiple political viewpoints. The goal of the interview subject selection was not to interview a random sample of community members, but rather to interview every individual who was involved in or very familiar with the decision process related to RICD water rights within these communities. Virtually all participants in the local community policy processes were interviewed for this study. Specifically, all water attorneys, and at least one (more when appropriate) individual from the government entity that obtained the water right were interviewed. The interview subjects were asked a panel of open-ended questions related to the actors, processes, and reasons for the RICD in their community. By using the same panel of questions, but being open to additional lines of questioning based upon the unique circumstances in each community, the researcher was able to gather data that could be compared across subjects and across communities (Rubin \& Rubin, 2005). Second, all legal and legislative documentation of the decision and application processes was analysed. This included all legislative documentation from the Colorado General Assembly, as well as all state court documents and local government documentation of decision processes. Finally, local news media coverage was gathered from each community's local newspaper. From each newspaper, all published material dating from 1997 (when available) until 2006 were searched. In two instances this search was done by hand using back copies of the newspaper and reading for any headlines containing words such as "kayak", "white-water", "recreational water right", and "RICD". Irrelevant articles were then screened out of the final database of news articles. In all other instances, the individual newspaper online archives were searched using the same keyword searches. For two newspapers - the Denver Post and Pueblo Chieftainnews aggregator websites such as Lexis Nexis were used since these newspapers are large enough to be included in the database. ${ }^{2}$ These data were then analysed to determine the stakeholders, participants, and influences that were important to policy change within each community.

Data analysis was performed by coding the data and then constructing within case narratives in order to then construct a cross-case analysis. Codes were initially created based upon the existing literature (Weston et al., 2001) to create a broad coding structure and then additional codes were created based upon the emergent categories in the data (Strauss \& Corbin, 1998; Weston et al., 2001). For example, literature on policy diffusion indicates that entrepreneurs, information, and geography may play important roles in the spread of policies among communities. Those categories were used as a starting point for the coding conducted here. Additionally, in these communities specific actors and categories of actors were mentioned as important to the spread of knowledge, the adoption of the policy, or the entrepreneurship that resulted in successful policy innovation. Codes related to these topics were created based upon the data. By breaking down the data into their basic concepts and frames through this coding process, it was possible to detect patterns in the data 
and determine influential variables in policy diffusion, while maintaining a focus on the research questions that drove the study.

These coding and data analysis procedures were conducted by using NVivo software, which helps to categorize and organize volumes of qualitative data sources. Coding of the data was done line-by-line so as not to take the qualitative data out of context. When searches of text were conducted using NVivo, the researcher always read the paragraphs immediately before and after key quotations so as to ensure accurate representation of each quotation included in the analysis. Each interview subject was assigned a code, which is used when a quotation from that subject is used in this paper. This code is used instead of other identifying information, such as community affiliation or job title, because in some instances this information would identify the interview subject due to limited participation in some small communities included in this study. The alphabetical code describing the subject's affiliation along with a number comprise the subject code. For example, local elected officials are coded as EL. These subjects are assigned codes EL-01 to EL-07. ${ }^{3}$ These codes assist in maintaining individual privacy for interview subjects and also aid in the categorization and accuracy of data reporting of the qualitative data used throughout the study.

Two complementary analytical processes were used in this research study. First, a within-case analysis was conducted to create a case narrative to explain the policy process, important actors, and reasons for RICD adoption within each community (Eisenhardt, 1989; Miles \& Huberman, 1984). These narratives draw on the data that were coded using the procedures outlined above. Second, a search for patterns was conducted among all cases based on the within-case analyses. The cross-case analysis was used to determine common patterns across case study communities in order to form the basis of research findings (Bourgeois III \& Eisenhardt, 1988; Eisenhardt, 1989). This second stage of analysis was necessary to develop an understanding of the common processes and influences among all RICD communities to understand the patterns of policy diffusion. All findings presented below are based upon the data and analysis conducted using multiple data sources and a two-stage data analysis procedure.

\section{Recreational Water Rights Policy Diffusion in Colorado Communities}

The individual case study analyses, which outlined how each RICD community learned about the option of applying for a recreational water right, indicate that experts were instrumental within communities in advocating for RICD water rights (Crow, 2010). In these cases, attorneys and local water managers experienced lower barriers to entry into local policy processes due to the trust, expertise, and specific skills they held. This section will investigate whether information about RICD water rights spread among communities in a similar manner and what effect that might have had. It is important to note that for the RICD policy to spread among communities, the policy information need only spread among elites. Water rights matters do not often see public participation, as was the case in this study (Crow, 2009). While the public was involved in some communities, as indicated below, policy diffusion could successfully take place with only dissemination of information among a small group of decision makers in each community.

With regard to how communities learned about RICD water rights in order for them to then consider it as an appropriate local policy option, in all of the early cases, the 
community's water attorney was integrally involved in uptake and dissemination of knowledge regarding this new policy option. As the RICD became better known through this information diffusion, community leaders and citizens also became sources of information regarding the policy option. Within half of the RICD communities, learning about the RICD policy option occurred as a direct result of attorney involvement and dissemination of expert knowledge. Later in the process, starting in Gunnison, citizens and staff members of government entities knew about the policy option and in some cases worked to initiate and advocate for the RICD application within the community. It is important to note that municipal water attorneys in Colorado are private attorneys who typically have multiple municipal clients. These attorneys specialize in issues related to water rights and advise their client communities on matters of water law, pursue water rights on behalf of their clients, and defend existing water rights. Several of the communities studied hereGolden, Vail, Breckenridge, Chaffee County, and Steamboat Springs-hired (or already had an established relationship with) attorneys from a single firm that specializes in water law. Additionally, these attorneys were consulted in several additional cases on an informal basis. In these cases, interview subjects indicated that the attorneys were considered the experts on RICD water rights due to their experiences beginning in Golden. Not only did Golden set the legal precedent, but it also established a public policy precedent related to the use of water for recreation and tourism in Colorado communities. The attorneys who represented Golden and other communities were quoted in media coverage, advised their clients to obtain the water rights, and advocated for the water rights in state legislative hearings on behalf of their clients. These attorneys, however, did not actively solicit additional clients or advertise their services to communities that could potentially benefit from such a water right. Table 2 lists the mechanism through which each RICD community initially learned about the RICD.

Table 2. RICD Community Learning Processes

\begin{tabular}{ll}
\hline Community & \multicolumn{1}{c}{ Learning Mode $^{\mathrm{a}}$} \\
\hline Golden & Attorney \\
Vail & Attorney \\
Breckenridge & Attorney \\
Longmont & Attorney and Staff \\
Pueblo & Attorney \\
Gunnison & Collective Understanding \\
Steamboat Springs & Citizen Initiative \\
Chaffee County & Citizen Initiative \\
Silverthorne & Attorney and Staff \\
Durango & Attorney and Collective Understanding \\
Avon & Collective Understanding \\
Carbondale & Attorney and Collective Understanding \\
\hline
\end{tabular}

Notes: ${ }^{\text {a }}$ All data presented in Table 2 are derived from interviews conducted in each community wherein subjects were asked how they personally learned about the RICD water right, how "others" learned about the RICD, and as far as they know how the community came to know about the new water right. Within each case study community, answers to these questions were compared among the subjects involved in that community's RICD process. Findings are only presented for those instances where there was agreement among interview subjects, indicating a consensus answer to the questions asked. 
The information important for local RICD decisions that was disseminated among communities consisted of knowledge about the policy option as a legally recognized water right, the costs associated with the RICD application process, the history of political opposition from state agencies and neighbouring water users in RICD communities, and the specific procedural requirements related to RICD applications. This information falls into two important categories - expert-driven information and "local knowledge" about the culture, politics, and geographic specifics of the community (Fischer, 2005). Once communities decided to apply for RICD water rights, the information necessary for success becomes much more community-specific and technical, including engineering, hydrologic studies, economic impact reports, and technical legal information. It was the first category-the expert information - that played an important role in policy diffusion between communities in Colorado.

As Table 3 illustrates, media coverage of previous RICD cases and attorney dissemination of knowledge regarding RICDs appear to have been the two primary modes of learning leading to the later "collective understanding" of the policy option presented by the six RICD communities listed in the table. One important dynamic highlighted in the table involves local reportage of the RICD water right. In several instances, local activists or government officials recounted learning about the RICD by reading media accounts and interviews. In each instance, reporters had interviewed one of two water attorneys, even when these attorneys were not personally involved in the RICD case being covered. This

Table 3. Mode of Community Learning About RICD Policy Opportunity

\begin{tabular}{|c|c|c|}
\hline Learning Mode & Communities & Examples of Relevant Qualitative Data \\
\hline Attorney & $\begin{array}{l}\text { Golden } \\
\text { Vail } \\
\text { Breckenridge } \\
\text { Longmont } \\
\text { Pueblo } \\
\text { Steamboat } \\
\text { Springs } \\
\text { Silverthorne } \\
\text { Durango }\end{array}$ & $\begin{array}{l}\text { "None of us people who practise water law in Colorado } \\
\text { hadn't at least generally heard of when. . .the Golden } \\
\text { case occurred and the legislation that occurred." } \\
\text { [WA-04] }\end{array}$ \\
\hline Media $^{a}$ & $\begin{array}{l}\text { Steamboat } \\
\text { Springs } \\
\text { Silverthorne } \\
\text { Avon }\end{array}$ & $\begin{array}{l}\text { "There was a quote in there from some guy [Golden's } \\
\text { water attorney]. . . and I said, 'well, I'm going to call } \\
\text { this guy up'. So I got his phone number and I called } \\
\text { him up.”[EL-01] }\end{array}$ \\
\hline $\begin{array}{l}\text { Collective } \\
\text { Understanding }\end{array}$ & $\begin{array}{l}\text { Gunnison } \\
\text { Silverthorne } \\
\text { Chaffee } \\
\text { County } \\
\text { Avon } \\
\text { Durango } \\
\text { Carbondale }\end{array}$ & $\begin{array}{l}\text { "It's so well known as an option or a tool that. . . how } \\
\text { could it not come up?" [EL-06] }\end{array}$ \\
\hline
\end{tabular}

Notes: ${ }^{a}$ Clearly, media coverage of RICDs can be a contributing factor, or even a primary factor, in the "collective understanding' mode of learning listed herein. This research is not able to differentiate between these modes of learning based on interview data, so they are listed separately, but with the acknowledgement that these two modes of learning may be interconnected at least tangentially. ${ }^{\mathrm{b}}$ Silverthorne and Avon share local newspapers with Breckenridge and Vail, so media coverage was present starting several years prior to these two RICD applications. 
pattern of repetitive journalistic sourcing helped to disseminate the professional reputation and knowledge of the small group of water attorneys mentioned above.

In addition to learning about RICD water rights as a policy option from other communities, it is important to consider what communities learned with regard to RICD water rights from earlier cases and whether communities actively tried to take lessons from earlier cases.

"We did our homework and reached out to other communities that were in the process or had gotten an RICD previously." [LG-19]

"I followed the Golden case, which was one of the earlier ones and then went down the line with Steamboat, watched the Gunnison." [EL-05]

"We tried to keep track of what was going on with different rights." [LG-22]

"I looked at what other communities had been doing, particularly looking at Golden.

Once they'd built their park they wanted to protect it to make sure that it would be operational." [LG-05]

RICD communities actively sought advice or lessons from communities that had undertaken their RICD applications previously, an encouraging finding for those scholars who advocate increasing use of knowledge in policy decisions (Healy \& Ascher, 1995; Michaels et al., 2006). This knowledge uptake is an important finding particularly in technical policy contexts since prior lessons and the corollary information regarding those lessons can presumably help improve later policy outcomes. Specific information was gathered by latecomers to the policy process regarding the earlier RICD cases, particularly about resources and expertise.

"We were aware that other communities had spent hundreds of thousands of dollars in the securing of recreational water rights in the state of Colorado." [LG-21]

"The lessons that we learned were. . . who should we contact in terms of experts." [LG-16]

"I went in front of city council with a couple other people and we said, 'hey you guys need to hire [Golden's attorney]. He's gotten the Golden case.'” [LR-04]

"We kind of followed them as the model for the application, for format. Being really the first to file under the new statute, we didn't know quite what to make of the language." [WA-05]

Early cases of RICD water right applications appear to have influenced later cases through this flow of information. In some of these later cases, specific information with regard to legal strategy, legal format, and potential costs and benefits of the water right were sought from communities that had already been through the process. The data above indicate that information, specifically technical information related to the RICD water right, legal requirements, and the policy process, was crucial in helping communities access the required resources and expertise to pursue the RICD water right.

Based on the literature presented in this paper, it was expected that policies would diffuse more readily among neighbouring governments where there may also be competitive economic pressure for policy diffusion, professional organizations, and where policies are 
less technical. This case analysis examines a particular case of technical policy diffusion wherein all case study communities are relatively proximate, so it is clear that technical policies are not innately unable to quickly diffuse through communities. The following section will evaluate the role of economic competition, professional organizations, and the vectors (Boushey, 2010) that promote diffusion.

Nine of the 12 case study communities are located in the Colorado mountains. The desire for these communities to obtain a water right is based at least in part on the fact that these communities have recreation and tourism dependent economies. Additionally, these nine communities are geographically suitable places for white-water boating. It is important to note that not all communities would potentially be suitable for a RICD water right and kayak course. Not only does a community need a river, but also geographically appropriate terrain to provide a recreational experience to attract kayak enthusiasts. The analysis finds that previous research indicating an influence of economic competition on policy transfer is accurate in several RICD cases. Gunnison, Carbondale, Steamboat Springs, Durango, Silverthorne, and Avon all show patterns of RICD adoption based partially on the fact that neighbouring competitors for tourism dollars and related tax revenue had built white-water courses and applied for water rights to protect the long-term viability of those courses. There is also an indication among RICD communities (with the exception of Longmont, Golden, and Pueblo) supporting the assertion that similar social needs or geographic connections will increase the likelihood of policy transfer. Many RICD communities rely significantly on tourism revenue for income. ${ }^{4}$ Additionally, several of these communities face similar patterns of second-homeownership, residents who demand recreational opportunities, and constituents who demand environmental protection of resources (Venturoni, 2004). ${ }^{5}$ These demographic and economic similarities among RICD communities may help to explain the ease with which policy diffusion took place. Within communities, not a single interview subject or document pointed to outside interest groups assisting in policy diffusion. In fact, outside actors were absent except for the water attorneys who are hired as outside counsel, state actors that opposed these water rights, and other water rights holders who opposed these water rights (as is typical in water court proceedings).

With regard to the professional nature of the organizations pursuing these water rights, there is virtually no variation. Of the most common forms of local governance, the councilmanager arrangement is generally considered the most professional and technocratic form of local governance. In these case studies (see Table 4 below), only Chaffee County has a government structure akin to the council-mayor form of government, in this case a county commission with an elected chair, while the rest rely on a manager structure. While this may indicate that technical policy diffusion is more likely among professional organizations, as supported by diffusion literature (Boushey, 2010), it may also indicate that due to the predominant nature of the council-manager structure, that most localities would be primed to accept the RICD policy.

In RICD cases, data support conclusions that geographic proximity and economic competition promote policy diffusion among neighbouring governments. Professional government structures were also found to be receptive to policy diffusion of technical environmental policies. The case study presented here does not attempt to generalize findings beyond this set of 12 cases or beyond Colorado water law. However, the lessons derived from this research provide some insight into potentially significant influences over policy diffusion among local governments. What stands out as a key finding here is that this technical policy was able to diffuse rapidly across Colorado, despite predictions to the contrary. 
Table 4. Costs of Recreational Water Rights

\begin{tabular}{|c|c|c|c|c|c|}
\hline Community Name & $\begin{array}{c}\text { Kayak } \\
\text { Course Costs }\end{array}$ & RICD Costs & Total Costs ${ }^{\mathrm{a}}$ & Population $^{b}$ & $\begin{array}{c}\text { Form of } \\
\text { Government }^{\mathrm{c}}\end{array}$ \\
\hline Golden & $\$ 350000$ & $\$ 160000$ & $\$ 510000$ & 17159 & Council-manager \\
\hline Vail & $\$ 150000$ & $\$ 300820$ & $\$ 450820$ & 4531 & Council-manager \\
\hline Breckenridge & $\$ 300000$ & $\$ 185000$ & $\$ 485000$ & 2408 & Council-manager \\
\hline Longmont & $\$ 486000$ & $\$ 46750$ & $\$ 532750$ & 71093 & Council-manager \\
\hline Pueblo & $\$ 300000$ & $\$ 400000$ & $\$ 700000$ & 102121 & Council-manager \\
\hline Gunnison & $\$ 250000$ & $\$ 600000$ & $\$ 850000$ & 5409 & Council-manager \\
\hline Steamboat Springs & $\$ 42400$ & $\$ 750000$ & $\$ 792400$ & 9815 & Council-manager \\
\hline Chaffee County & $\$ 500000$ & $\$ 250000$ & $\$ 750000$ & 16242 & $\begin{array}{l}\text { County } \\
\text { commission } \\
\text { with a chair }\end{array}$ \\
\hline Silvert & $\$ 450000$ & $\$ 50000$ & $\$ 500000$ & 3169 & Council-manager \\
\hline Durango & $\$ 600000$ & $\$ 300000$ & $\$ 900000$ & 13922 & Council-manager \\
\hline Avon & $\$ 560000$ & $\$ 208000$ & $\$ 768000$ & 5561 & Council-manager \\
\hline Carbondale & $\$ 550000$ & $\$ 70000$ & $\$ 620000$ & 5196 & Council-manager \\
\hline Mean & $\$ 378200$ & $\$ 276714$ & $\$ 654914$ & 21385 & \\
\hline Median & $\$ 400000$ & $\$ 229000$ & $\$ 660000$ & 7688 & \\
\hline
\end{tabular}

Notes: ${ }^{\text {a }}$ All costs associated with kayak course construction and RICD legal costs were obtained from interviews with 1) city managers, utility personnel, recreation personnel, or planners involved in the construction of the kayak courses in each community and 2) the water attorney in each community who reported the costs that their client communities paid for the RICD water right.

b Population data from the 2000 census was used for this study because the timeframe for each RICD case corresponded most closely with the 2000 census.

${ }^{c}$ Information regarding the governmental structure in each community was gathered from either the community charter or the community government website.

We also see that experts and media played important roles in disseminating the required information to successful policy diffusion, rather than outside interest groups as several studies of state-to-state diffusion have found.

\section{Conclusions}

The analysis presented in this paper addresses the processes by which policy diffusion and information diffusion took place in Colorado RICD communities. Based on evidence from RICD communities, it is clear that accurate knowledge about policy options, resources, and expertise was important for policy diffusion. This paper presented evidence related to the mode of learning about the RICD policy within RICD communities. The most common mode of learning was through experts - or local water attorneys. Half of the RICD communities also learned about the RICD policy option at least partially through a collective understanding derived from policy history throughout Colorado and the various sources of information dissemination therein. While interest groups did not play a role in helping spread policies to neighbouring communities, experts acting as policy entrepreneurs within communities played the role of information entrepreneurs in helping to spread RICD information to other Colorado communities. These experts also acted as information entrepreneurs in their contacts with reporters at media outlets in Colorado who quoted a small group of experts repeatedly. It appears that the influence of these expert information entrepreneurs is most apparent early in the process of policy diffusion, before the policy is widely known. 
This case analysis highlights several findings that are relevant to our expanding understanding of policy diffusion. First, while it does appear that economic competition and geographic proximity to other policy adopter communities played a role in the RICD case, with the predominance of increasingly professional forms of government such as the council-manager structure, even highly technical policies like the RICD water right can rapidly diffuse through communities that otherwise might not be likely to consider such a policy, based only on community resources or organization size. Increasingly, policymaking is becoming professionalized and reliant on more technical policy and expert information (Schneider \& Ingram, 1997; Weimer \& Vining, 1999). Beyond those areas that have traditionally been bastions of expert-based policymaking, technocratic policymaking is becoming increasingly prevalent in social policy, education policy, and other formerly non-scientific fields of policy. This is important when we consider how policies diffuse, because it may no longer be appropriate to define policies as technical or non-technical.

Finally, while this study highlights some key findings, among them the importance of experts in disseminating information among local governments through various means including media, future studies should attempt similar analyses with a comparative policy method. While this case was appropriate for a number of reasons, including the increasing trend towards technocratic policymaking, it would be helpful to compare this case to a similar one in which a purely moral or political policy diffused among local governments. This would help account for the limitations of this study, including the predominance of professionalized governance structures and the complex nature of water rights policy.

\section{Notes}

1. This water right was based on previous legal precedent in similar cases in Fort Collins, Aspen, and Westminster.

2. Newspapers included for this study were: Denver Post, Rocky Mountain News (closed in 2009), Pueblo Chieftain, Longmont Times-Call, Summit Daily, Vail Daily, Chaffee County Mountain Mail, Steamboat Pilot and Today, Gunnison Country Times, Durango Herald, and Carbondale Valley Journal.

3. Codes for interview subjects: $\mathrm{EL}=$ Local elected official; $\mathrm{ES}=$ State elected official; $\mathrm{CW}=$ Colorado Water Conservation Board employee; $\mathrm{CO}=$ Other state agency employee; $\mathrm{LR}=$ Local recreation interest; WA $=\mathrm{Water}$ attorney; $\mathrm{LG}=$ Local government employee; $\mathrm{LW}=$ Local water provider; $\mathrm{WP}=$ Other water provider; $\mathrm{ER}=$ Environmental or recreation interest; $\mathrm{RE}=$ Recreation engineer.

4. Major tourism hubs are found in: Vail, Breckenridge, Silverthorne, Avon, Durango, Chaffee County, and Steamboat Springs. Less prominent, but still locally important are tourism economies in Gunnison and Carbondale.

5. Which, due to the non-consumptive and in-stream flow nature of these water rights, RICDs help promote.

\section{References}

Bell, S. (2004) "Appropriate" policy knowledge, and institutional and governance implications, Australian Journal of Public Administration, 63(1), pp. 22-28.

Berry, F. S., \& Berry, W. D. (1990) State lottery adoptions as policy innovations: An event history analysis, American Political Science Review, 84(2), pp. 395-415.

Bikhchandi, S., Hirshleifer, D., \& Welch, I. (1998) Learning from the behavior of others: Conformity, fads, and informational cascades, Journal of Economic Perspective, 12(3), pp. 151-170.

Bingham, R. D. (1978) Innovation, bureaucracy, and public policy: A study of innovation adoption by local government, The Western Political Quarterly, 31(2), pp. 178-205.

Boehmke, F. J., \& Witmer, R. (2004) Disentangling diffusion: The effects of social learning and economic competition on state policy innovation and expansion, Political Research Quarterly, 57(1), pp. 39-51.

Bourgeois III, L. J., \& Eisenhardt, K. M. (1988) Strategic decision processes in high velocity environments: Four cases in the microcomputer industry, Management Science, 34(7), pp. 816-835. 
Boushey, G. (2010) Policy Diffusion Dynamics in America (New York, NY: Cambridge University Press).

Busenberg, G. J. (2008) Managing the hazard of marine oil pollution in Alaska, Review of Policy Research, 25(3), pp. 203-218.

Colorado Foundation for Water Education. (2004) Citizen's Guide to Colorado Water Law (Denver, CO: Colorado Foundation for Water Education).

Crow, D. A. (2009) Responsive public officials and engaged citizens: Myth or reality? A case study of water rights policy in Colorado, Public Organization Review, 9(2), pp. 119-138.

Crow, D. A. (2010) Local media and experts: Sources of environmental policy initiation? Policy Studies Journal, 38(1), pp. 143-164.

Dolowitz, D. P., \& Marsh, D. (2000) Learning from abroad: The role of policy transfer in contemporary policymaking, Governance: An International Journal of Policy and Administration, 13(1), pp. 5-24.

Eisenhardt, K. M. (1989) Building theories from case study research, The Academy of Management Review, 14(4), pp. 532-550.

Fischer, F. (2005) Citizens, Experts, and the Environment: The Politics of Local Knowledge (Durham, NC: Duke University Press).

Getches, D. H. (1997) Water Law: In a Nutshell (St. Paul, MN: West Publishing).

Glick, H. R., \& Hays, S. P. (1991) Innovation and reinvention in state policymaking: Theory and the evolution of living will laws, Journal of Politics, 53(3), pp. 835-850.

Godwin, M. L., \& Schroedel, J. R. (2000) Policy diffusion and strategies for promoting policy change: Evidence from California local gun control ordinances, Policy Studies Journal, 28(4), pp. 760-776.

Grossback, L. J., Nicholson-Crotty, S., \& Peterson, D. A. (2004) Ideology and learning in policy diffusion, American Politics Research, 32(5), pp. 521-545.

Haas, P. M. (2004) When does power listen to truth? A constructivist approach to the policy process, Journal of European Public Policy, 11(4), pp. 569-592.

Hays, S. P. (1996) Influences on reinvention during the diffusion of innovations, Political Research Quarterly, 49(3), pp. 631-650.

Healy, R. G., \& Ascher, W. (1995) Knowledge in the policy process: Incorporating new environmental information in natural resources policy making, Policy Sciences, 28(1), pp. 1-19.

Hobbs, G. J. (1997) Colorado water law: An historical overview, University of Denver Water Law Review, 1(1), pp. $1-138$.

Hoyman, M., \& Weinberg, M. (2006) The process of policy innovation: Prison sitings in rural North Carolina, Policy Studies Journal, 34(1), pp. 95-112.

Layzer, J. A. (2002) Citizen participation and government choice in local environmental controversies, Policy Studies Journal, 30(2), pp. 193-207.

Meseguer, C. (2006) Rational learning and bounded learning in the diffusion of policy innovations, Rationality \& Society, 18(1), pp. 35-66.

Michaels, S., Goucher, N. P., \& McCarthy, D. (2006) Considering knowledge uptake within a cycle of transforming data, information, and knowledge, Review of Policy Research, 23(1), pp. 267-279.

Miles, M. B., \& Huberman, A. M. (1984) Drawing valid meaning from qualitative data: Toward a shared craft, Educational Researcher, 13(5), pp. 20-30.

Miller, T. I. (1989) Gut-level decision making: Implications for public policy analysis, Journal of Policy Analysis and Management, 8(1), pp. 119-125.

Mintrom, M. (1997) Policy entrepreneurs and the diffusion of innovation, American Journal of Political Science, 41(3), pp. 738-770.

Nicodemus, D. M. (2004) Mobilizing information: Local news and the formation of a viable political community, Political Communication, 21(2), pp. 161-176.

Rubin, H. J., \& Rubin, I. S. (2005) Qualitative Interviewing: The Art of Hearing Data (Thousand Oaks, CA: Sage Publications).

Schneider, A. L., \& Ingram, H. (1997) Policy Design for Democracy (Lawrence, KS: University Press of Kansas). Simon, H. A. (1976) Administrative Behavior (New York, NY: Free Press).

Strauss, A., \& Corbin, J. (1998) Basics of Qualitative Research: Techniques and Procedures for Developing Grounded Theory (Thousand Oaks, CA: Sage Publications).

Tews, K., Busch, P. O., \& Jorgens, H. (2003) The diffusion of new environmental policy instruments, European Journal of Political Research, 42(4), pp. 569-600.

Venturoni, L. (2004) The Social and Economic Effects of Second Homes (Silverthorne, CO: Northwest Colorado Council Of Governments). 
Webber, D. J. (1991) The distribution and use of policy knowledge in the policy process, Knowledge \& Policy, 4(4), pp. 6-35.

Weimer, D., \& Vining, A. (1999) Policy Analysis: Concepts and Practice (Englewood Cliffs, NJ: Prentice-Hall).

Weston, C., Gandell, T., Beauchamp, J., McAlpine, L., Wiseman, C., \& Beauchamp, C. (2001) Analyzing interview data: The development and evolution of a coding system, Qualitative Sociology, 24(3), pp. 381-400.

Worster, D. (1985) Rivers of Empire: Water, Aridity, and the Growth of the American West (New York, NY: Oxford University Press).

Yin, R. K. (2003) Case Study Research: Design and Methods (Thousand Oaks, CA: Sage Publications). 